\title{
E-prescription. Selected legal and functional aspects
}

\author{
Szczepan Jakubowski ${ }^{1}$ (i) https://orid.org/0000-0001-6419-9686 \\ Artur Romaszewski ${ }^{1}$ (D) htps://orid.org/0000-0003-3416-716X \\ Joanna Wypyszewska \\ Krzysztof Gajda ${ }^{1}$ (D) https://orid.org/0000-0002-3294-7851 \\ Mariusz Kielar ${ }^{1}$ (1) https://orid.org0000-0002-9531-7777
}

\begin{abstract}
${ }^{1}$ Medical Information Systems Department, Institute of Public Health, Faculty of Health Sciences, Jagiellonian University Medical College

Address for correspondence: Szczepan Jakubowski, Instytut Zdrowia Publicznego, Grzegórzecka 20, 31-531 Kraków, szczepan.jakubowski@uj.edu.pl
\end{abstract}

\section{Abstract}

This article is to present the concept of the electronic prescription model, taking into account legal regulations and technical solutions. Nowadays important changes have happened. In 2018, a law package regarding e-prescriptions was introduced in Poland that creates a new tool (electronic prescription) in the Polish market. Homogeneous tools enabling the security and integrity of e-documents and the approval of electronic signatures and seals are particularly important for the operation of the e-prescription. To enable the transmission of e-prescriptions it is required to join basic information and communications technology (ICT) system that supports e-prescribing to the main electronic identification system called Identification Electronic Node. In order to implement the e-prescription model, the lanuching of electronic medical records is indispensable. In most EU countries the e-prescription is implemented with the interchange standard of medical records called Health Level Seven (HL7). In terms of identification and authentication in e-prescribing, the elDAS regulation plays a significant role. The electronic prescription has long been used in many countries, among which Sweden was one of the earliest (Sjunet system). Patients, physicians, pharmacies and the state will all benefit from the implementation. Ultimately, prescribers would have to use tools that will make it possible to ensure the confidentiality, integrity and credibility of transactions.

\section{Key words: electronic prescription, leyal regulations, e-prescription system model, standards, trust services}

\section{Stowa kluczowe: recepta elektroniczna, regulacje prawne, model systemu e-recept, standardy, ustugi zaufania}

Ministerstwo Nauki

i Szkolnictwa Wyższego
Przygotowanie do wydania elektronicznego finansowane w ramach umowy 641/P-DUN/2018 ze środków Ministra Nauki i Szkolnictwa Wyższego przeznaczonych na działalność upowszechniającą naukę.

\section{The objective of the article}

This article is to present the concept of the electronic prescription model (e-prescription) in view of EU and national regulations, and the legal and technical solutions necessary for its functioning, as well as to explain the concepts related to identification and to trust services. New regulations have introduced a number of legal institutions and concepts related to them - specifically, the concept of trust services, the use of which is neces- sary to launch and develop the e-prescription project, i.e. creation of electronic signatures, electronic seals, electronic time stamps and registered electronic delivery services.

\section{Prescription - definition and types}

A prescription is a written instruction directed to a pharmacist, issued by an authorized entity under the binding regulations [1]. It concerns mainly medicines and medi- 
cal devices or foodstuffs intended for particular nutriotional uses.

The content of the prescription (also an electronic prescription) is specified in the regulations. The data that are necessarily to be included in each prescription are:

1) patient data (name, surname, address, patient ID, etc.);

2) data regarding the entity where the prescription was issued or the person who issued the prescription (address, name, identifier of the service provider, etc.);

3) data regarding the person issuing the prescription (name, surname, employee ID, employee signature, etc.);

4) data regarding the prescribed medicinal product, foodstuff intended for specific nutritional uses or a medical device (commonly used name or trade name, drug form, dosage, quantity, etc.);

5) data regarding the date of executing the prescription (issue and execution);

6) a unique number identifying the prescription (transmitted by the ICT system or the director of the voivodship branch of the National Health Fund (Pol. NFZ);

7) marking indicating for whom the prescription is issued if the prescription is written out for a relative (Art. 96a) [1, 2].

The prescription is part of medical documentation, but also a self-functioning document and has an effect for both the patient who receives the funds necessary for therapy, and for the health care system - in the case of therapy financed or co-financed from public funds. Therefore, it is of utmost importance that the substances ordered under the prescription go to people correctly diagnosed and that they are issued by appropriately authorized entities. This is to prevent a situation where some of the preparations purchased on their basis be sent to unauthorized persons, or even to feed their circulation on the black market (including psychotropic drugs, steroids).

Based on the type of media on which the prescriptions are issued, we can distinguish paper and computerized prescriptions (the name proposed by the authors of the article). Electronic prescriptions (e-prescriptions) constitute a separate category because their functioning requires a properly developed and functioning IT system.

A paper prescription is a traditional medical document containing elements required by law, which are necessary for its correctness and for it to be admitted to marketing. The entities authorized to issue a prescription are: a doctor, a dentist, a doctor's assistant, a senior doctor's assistant, and in the case of certain predetermined medicines and medical devices (excluding foodstuffs intended for specific nutritional uses), a nurse and midwife [1]. The paper prescription model is based on the presupposition that the person who signed the prescription is actually the person whose name appears on the seal and is entitled to issue the document. In addition, each prescription written out to a patient should be related to their medical records. In practice, it is very difficult to verify the identity of the person signing the prescription, as well as verify their rights, both in relation to prescribing a given medicine and the correctness of the reimbursement for a drug. In conclusion, it should be noted that - apart from the substances written out - an integral part of the prescription is the seal and signature of the person issuing it. Also, the medium and information contained in paper medical documentation form a coherent whole.

Computerized prescriptions, on the other hand, are those that operate in electronic form, but the condition for marketing them is to change their form from electronic to paper. They are most often defined in programs that support keeping electronic documentation by entities providing health services. They allow one to print the prescription in accordance with the formula defined in the regulations. However, in order for it to be admitted to marketing is it having appropriate seals of the institutions, codes and, above all, a handwritten signature by the authorized person together with an individual seal stating the powers of the signer. In this case, we are dealing with a paper prescription, generated with the help of IT tools.

The basic difference between a paper and electronic prescription is related to the fact that in the case of the former we deal with a single document consisting of the seal and signature of the person creating the document - any corrections or additions are possible in the cases provided by law, and they do not affect the validity of the document.

In the latter case, the signature is related to the content (to the data signed) in such a way that any subsequent change of data will be recognizable. In this concept, the electronic signature placed on the prescription is uniquely assigned to the signer, which makes it possible to determine their identity. In contrast, an identity confirmation system (that could be created) should be a system that would be separate from the document itself, operating in such a way that any interested entity could determine the identity of the person signing the document. Also, a system needs to be created that would confirm the powers of the person issuing the prescription at the time of issuing it, i.e. a person authorized to practice, which by law is indicated as a necessary requirement to issue a prescription.

\section{Electronic prescription}

\subsection{Implementation of the concept of the e-prescription in Poland}

In force since January 2012, the act on the health information system is one of the most important documents paving the way for solutions within the area of e-health [3]. The regulations adopted therein enabled the development of the electronic medical record system, data authorization system, electronic referral (e-referral) or electronic prescription (e-prescription). The scope of practical functionalities of the electronic prescription and its planned introduction to general use on 1 January 2020 is to be a key condition for improving the organization of the treatment process in our country - in relation to both 
residential and outpatient care as well as health services provided by remote care services (e.g. teleconsultations).

The widespread introduction of the electronic prescription system is associated with a number of benefits for the various interested groups in the healthcare system. From the patient's perspective, the most important thing is to overcome the problem of illegibility of prescriptions, saving time, increased safety of therapy, the possibility of better coordination of the treatment process and improving the care of chronically ill patients. The entity issuing the electronic prescription saves its time and reduces the costs associated with issuing prescriptions in paper form. In turn, the entity executing the prescription acquires full legibility and credibility of the prescription, which simplifies the process of its execution. For the healthcare system, this solution means, first of all, sealing off the prescription system and drug circulation, obtaining strict control over the turnover of reimbursed drugs, current access to information on replacement medicines, and the possibility of linking individual groups and types of drugs to the epidemiology of specific diseases in the population [4]. Some authors, however, show more reservation towards the idea of the electronic prescription model in Poland, in their opinion resulting from fear of an imprudent growth of remote services in health care, as an alternative to traditionally understood medical art requiring a direct contact between the doctor and the patient [5].

Regarding the effectiveness of the implementation of the e-prescription system, Poland is unfortunately occupying a distant position. There are countries that have long used the electronic prescription transfer in their healthcare systems. It is worth recalling that as early as in 2008, the European Commission clearly stressed its expectations for the member states to make more progress in introducing e-prescriptions [6]. At that time, electronic prescriptions already functioned in several European countries. Looking at the facts, our delay in this area is even more vivid - Great Britain has been using e-prescriptions since 2005, Denmark since 1992, and the first works on the implementation of electronic prescription transfer in Sweden began in 1983. Moreover, even developing countries formerly referred to as 'Third World countries' (e.g. India or Brazil) currently use such systems, and Russia launched e-prescriptions in 2014 [7].

In February this year, another pilot study of e-prescriptions began in the Polish towns of Siedlce and Skierniewice, while on 18 April, 2018, a package of legislative acts introducing a widespread use of e-prescriptions $[2,8]$ came into force. By the end of 2018, all pharmacies and pharmaceutical agencies in Poland are to have been included in the integrated P1 platform. The process of creating the electronic P1 platform is supervised by the Health Care Information Systems Centre. The goal of the undertaking is to construct a tool for collecting, analyzing and sending electronic data on medical (and other) incidents to the extent compliant with the Act of 28 April 2011 on the information system in health care [9]. Then the e-prescription module will be activated in the treatment entities [10].

\subsection{E-prescription as an element of electronic medical documentation}

Electronic medical documentation (Pol. EDM) and eprescription, which it is a part of, are solutions that are dynamically entering the Polish information system health care (Pol. SIOZ) [3]. The advancement of technological solutions currently available on the market enables the introduction of fast and secure systems, allowing the processing of large amounts of data and information in a short time, in this way facilitating the introduction of solutions that have been awaited by patients and the medical community for years. These include e-prescriptions and other electronic medical documents that are required to receive a service or product (e.g. e-referral or e-orders).

As a medical document, the e-prescription is regulated by both national and international law. Work is underway on the possibility of using the e-prescription, as well as other electronic medical documents, throughout the European Union (EU), regardless of the place where the document was issued. The possibility of patients benefiting from cross-border healthcare was regulated in the European Parliament and Council's Directive 2011/24/ EU of 9 March 2011, on the application of patients' rights in cross-border healthcare [11]. However, the Commission's Implementing Directive 2012/52/EU of 20 December 2012, specifying the measures facilitating the recognition of medical prescriptions issued in another Member State [12], lists the minimal elements that must be included in medical prescriptions for them to be recognized in another EU country.

Since the e-prescription is an electronic document, it is appropriate to clarify the definition of an electronic document, which differs in Polish and European (EU) law. The Polish act on the computerization of entities performing public tasks [13] defines the electronic document as "a separate data set confined in a specific internal structure and stored on an IT data medium" (Art. 3.2), where the IT data medium is "a material or device used to record, store and read data in digital form" (Art. 3.1) [13], while the definition adopted by the Regulation No. 910/2014 of the European Parliament and of the Council of 23 July 2014 on electronic identification and trust services for electronic transactions in the internal market and repealing Directive 1999/93/EC, Electronic Identification, Authentication and Trust Services, eIDAS [14] is slightly wider. It allows free use of the technologies and is not limited to one type of medium. According to it, an electronic document is understood as "any content stored in electronic form, as a text, visual, audio or audiovisual recording", thus creating the freedom to use any technology for data storage [14]. Additionally, the e-prescription can be included in the medical documentation of an individual, external type, which by definition is intended for the patient using medical services of a given provider [15].

Due to the fact that the e-prescription will be processed on the P1 platform and the Patient Internet Account (Pol. Internetowe Konto Pacjenta, IKP) module, in 
the future, it will correspond to the standard of electronic information exchange in the medical environment (The Health Level Seven, HL7), adopted in the document "Poland Implementation of the National HL7 CDA (Clinical Document Architecture)" [16]. The application of this standard is to help IT service providers to standardize templates and procedures for creating, storing and sending electronic documents between various entities [8, 16].

\subsection{Features of the electronic prescription}

In a standard system (of some EU countries; see Chapter 7. Electronic prescription in other countries), e-prescription is the electronic final document of an information system (national or regional), which in addition to the content relevant for the prescription, also contains technical solutions that enable, i.a.:

- determining the identity of the person signing the e-prescription and confirming the right of that person to issue such documents and writing out specific medicines (including the contract with the NHS (Pol. NFZ) for the provision of services and issuing prescriptions for reimbursed drugs);

- detection of all data changes (integrity) following its issue;

- the impossibility of denying the signature by the author and the seal issued by the institution;

- the verification of the signature of the person who signed the prescription and the entity under which the signer provides services, by any interested party (person or institution).

The e-prescription as a carrier of health data must be properly secured. It is part of the medical documentation, but it should be operated by a separate IT system. Therefore, it is necessary to ensure cooperation between both systems, because the electronic prescription, as part of the medical documentation, must be compatible with the documentation functioning in the therapeutic entity.

\subsection{Security of the e-prescription}

Multidirectional works are underway in the EU, whose aim is to introduce uniform laws regarding the identification of all persons and institutions using information systems to process electronic documents [14] - including electronic medical documentation. So far, uniform solutions have been introduced regarding the creation, securing and trading of electronic documents as well as the possibility of verifying the origin of the document and its creator or institution that has the right to disseminate it. These solutions have been introduced by the eIDAS Regulation [14], together with national laws that supplement its provisions [17]. The safety of personal data, including patient data, has also been uniformly regulated throughout the EU (RODO) [18]. The health care sector is also covered by the provisions of the Act of 5 July 2018 on the National Cyber Security System [19] - developed on the basis of the Directive of the European Parliament and of the Council (EU) 2016/1148 of 6 July 2016 on measures for a high common level of security of network and information systems in the territory of the European Union [20]. The purpose of the provisions of the Act on the national cyber security system is to ensure the resilience of information systems, including health care, to activities that violate the confidentiality, integrity, availability and authenticity of the data processed or related services offered by these systems.

The electronic prescription is subject to the safety standards contained in the eIDAS Regulation. Both the electronic identification system and the electronic means of identification are protected - meaning a "tangible or intangible unit containing person identification data and used for authentication purposes for an online service" (Article 3.2) [14]. There are three security levels of the two elements mentioned above (system and means of identification): low, medium and high. The higher the level, the more secure the security mechanisms are, and the data you want to access receive the status of sensitive and confidential data. [21]. Due to the level of data sensitivity in health care, a high level of security is recommended in electronic identification systems [22]. The high level is characterized by a wide range of trust in the identity of people and concerns technical specifications, procedures and standards. This is to prevent the risk of impersonating a person or modifying their identity. At this level, it is recommended that two or more authentication factors (i.e. characteristics of a given person with a confirmed origin and relationship) contained in the electronic identification and the obligation for all EU countries to recognize this tool [2].

In entities that carry out medical activities (e.g. enterprises, independent public health care units [Pol. SP ZOZ]), there may be ICT systems that are subject to the act on the computerization of entities performing public tasks [13]. An ICT system is an IT system created to support a given area of health protection [3]. If a given ICT system allows access to the patient's electronic medical records, persons who want to access these data must undergo the authentication process - confirmation of the origin and integrity of verified electronic data assigned to the identity. The authentication process includes:

1) "electronic means of identification issued in the electronic identification system connected to the national electronic identification node;

2) electronic means of identification issued in the notified electronic identification system, or

3) data verified by means of a qualified electronic signature certificate, if these data allow the identification and authentication required for the provision of the online service" (Article 20a.1) [13].

In conclusion, the e-prescription model and the system supporting this tool to ensure data security must meet the many requirements contained in Polish and EU law.

\section{Models of e-prescriptions}

One of the necessary conditions for the electronic prescription to be implemented in a given area is the earlier launch of electronic health records (EHR). In addition to the e-prescription, it provides such services as a patient 
portal, authorization services or access to remote medical consultations. An e-prescription is defined as prescribing medicines using software and by an authorized entity, for the purpose of dispensing medicines in a pharmacy after sending it electronically [23]. An important feature of the e-prescription is the fact of recording the data on the issued drug in the patient's medical records, and for this it is necessary to implement the EHR system.

Following their visit and authorization from the GP, the patient receives an entry in their medical records about the medicine that has been prescribed. Then, in the pharmacy, also after authorization, the patient receives the prescribed medicine, and the fact of its release is recorded in the electronic documentation (EHR). This enables all medical entities to view, among other things, the history of the medicines and pharmaceuticals issued and purchased. In this model, the payer of services (e.g. the National Health Fund, Pol. NFZ) also has information on the entire history, not only the medicines issued, but other medical services. The patient has the opportunity to view their history through the patient's portal, which uses the data stored in the EHR as an integrated 'data warehouse'. This solution is possible after at least two conditions have been met:

1. in the area where EHR has been implemented, there is a uniform standard for recording and transmitting medical data in an electronic form. The standard for electronic information exchange in the medical environment is dominant (The Health Level Seven Version 3, HL7 v 3.0);

2. IT systems of service providers have the option of recording data in the XML format (Extensible Markup
Language), which ensures interoperability of medical documents in electronic form.

In the case of the HL7 v. 3.0 standard, it should be mentioned that the minimum condition for the implementation of an electronic document is the development of HL7 CDA (Clinical Document Architecture) templates, and the optimal procedure is the development of an integrated reference model (Reference Information Model, HL7 RIM) based on a set of minimum data (Minimum Data Set, MDS). HL7 RIM gives the possibility to develop the entire system of circulation and storage of universal medical data for all entities interested in the population's medical data. What is also indispensable is system integration and for this purpose technological rails, or tools used for transporting data packets (messages) are used. In terms of system integration, two types of rails are used:

1. IHE (Integrated Healthcare Enterprises), which defines and coordinates existing Digital Imaging and Communications in Medicine (DICOM) and HL7 standards to support specific medical requirements related to patient care.

2. XDS (eXtended Data Distribution System), which is a software solution based on an extended communication protocol (File Transfer Protocol, FTP), in the client-server architecture used to create a data transmission network.

The flow of documentation in the context of HL7 is shown in Figure 1.

Figure 1 presents a chart of the electronic documentation flow based on HL7 RIM and the IHE/XDS com-

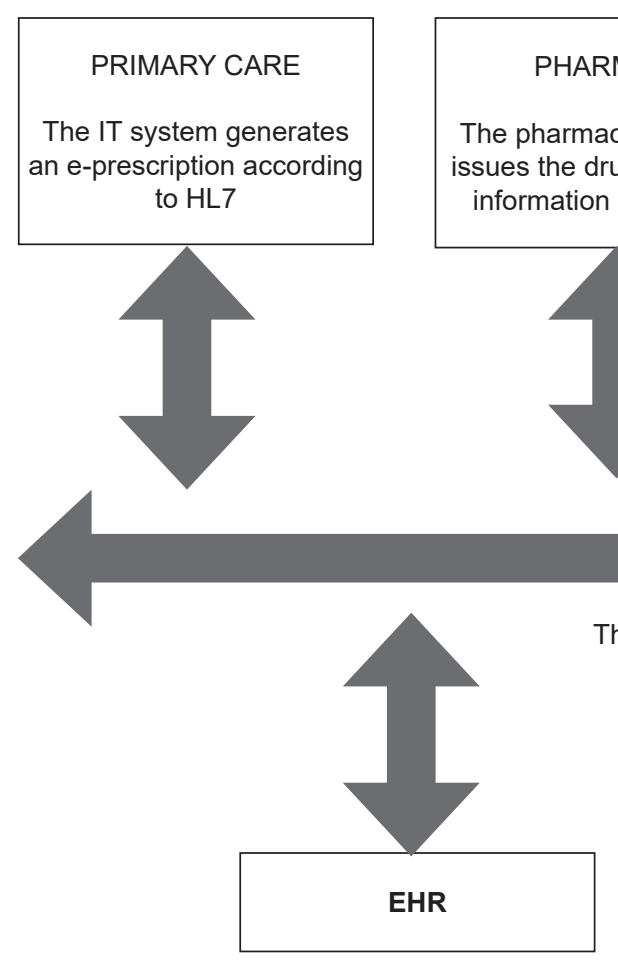

The IHE/XDS communication system transports individual XML files modelled with the HL7 standard
Information about the e-prescription is saved in the EHR (database)
Identification with a chip card or an ID card

Figure 1. The flow of documentation in the context of HL7.

Source: Own elaboration. 
munication system. The effect of modelling based on the HL7 standard is a set of XML Schema files, which describe what the messages should be like.

The implementation of the e-prescription based on the HL7 model is essential in the context of cross-border medical care. In most countries of the present European Union, the e-prescription has already been implemented and HL7 is used as the standard for the exchange of medical records. In 2018, the European Commission launched the initiative of the e-health digital infrastructure (eHealth Digital Service Infrastructures, eHDSI, e-health DSI). This is the initial implementation and running of services related to the cross-border exchange of health data under the Connecting Europe Facility (CEF). eHDSI configures and initiates the implementation of basic and general services, for cross-border care of patients, and the issuing of e-prescriptions. The implementation of general services is necessary for data exchange at the national level, while basic services - at the EU level [24]. Together, these services enable the provision of crossborder e-health information services [25]. The abovementioned documents show diagrams for different cases of individual medical events. One of them is the purchase of the medicine in a different country than where it was prescribed.

The primary purpose of the Electronic Patient Record (EPR) in the eHDSI model is to provide key patient health data during the provision of an unscheduled medical service, which can affect treatment. This type of events may unfold in the following way [23]:

1. The entity is uniquely identified and authenticated in its local system, according to its profile.

2. The patient identifies himself/herself in the system.

3 . The entity checks and confirms the identification provided.

4. Once the patient has been clearly identified through the appropriate authorization system, the entity may become familiar with their health data.

5. Before any information is provided to the entity, the patient must give their voluntary consent. Refusal to give consent is possible only in the case of protection of the vital interest of the patient or other person in an emergency, when the patient (the data subject) is physically or legally incapable of giving consent.

6. Information from country A should be presented to other entities in an orderly manner and based on national standards that are legible for country B. The information displayed by the entity in country B should be understandable (therefore, the available coding systems should be used).

7. A copy of the original information from country A may be shown to the entity in country B, if necessary (e.g. in the PDF version).

Such solutions can be used only when the implemented medical documentation in electronic form will be based on a uniform and known standard. When designing the model of the e-prescription in Poland, it is worth considering the provisions regarding the recognition of this document in European Union member states (defined i.a. in the Commission Implementing Directive 2012/52/
EU of 20 December 2012 establishing measures facilitating the recognition of medical prescriptions issued in another Member State) [12]. The e-prescription model developed by the Centre for Healthcare Information Systems (Pol. CSIOZ) is based on the HL7 CDA standard. The templates of electronic documents were developed after prior consultations of "Version 1.2 of business rules and validation of electronic medical documents". The templates concern: a prescription issued by a pharmacist at a pharmacy, a prescription for direct import, and a prescription that meets the requirements for a refund [26]. According to the assumptions published by the CSIOZ [9], the e-prescription flow will include the following:

Step 1. The doctor issues and digitally signs an e-prescription.

Step 2. The patient receives a print-out of the e-prescription or electronically as an e-mail or SMS with a 4-digit code.

Step 3. The patient arrives at the pharmacy.

Step 4. The pharmacist scans the code from the printout or from the telephone.

Step 5. The patient receives the medication.

\section{Trust services. The role of e-signature, e-seal, and other legal and technical solutions}

In addition to EU laws that set out the measures facilitating the recognition of medical prescriptions issued in a Member State other than the Member State of their execution [12], an important role is played by the laws on the tools required for the secure circulation of electronic documents (eIDAS). These tools are trust services, defined as electronic services, usually payable, and including:

a) "Creation, verification and validation of electronic signatures, electronic seals or electronic time stamps, electronic registered delivery services and certificates related to these services; or

b) creation, verification and validation of website authentication certificates; or

c) maintenance of electronic signatures, seals or related certificates with these services" [14].

A standard paper prescription must be signed with a handwritten signature (entailing legal consequences), and therefore, an e-prescription should also be signed with an electronic signature guaranteeing the recognition of the document in a legal context.

The electronic signature is directed to natural persons and is defined as "data in electronic form, which are attached or logically linked with other data in electronic form and are used by the signer as a signature" (Art. 3.10) [14]. These days, in the health care sector in Poland, a medical specialist has at their disposal three methods of electronic signing, namely using a trusted signature, a qualified electronic signature, or using a tool (certificate) made available by the teleinformation system of the Social Insurance Institution [Pol. ZUS, 27].

The electronic signature includes three main types regulated in the territory of the European Union. However, in the relations between the service provider and the service recipient (physician - patient), the qualified 
electronic signature can be validly used. It ensures integrity with the document and the identification of the signer, ensures the visibility of subsequent changes to the document, is subject to maintenance and validation, has a qualified certificate, and yields legal effects equal to the handwritten signature. The method of submitting this signature is only via a qualified device (e.g. an electronic card reader connected to a computer) $[14,28]$.

In addition, other electronic tools are dedicated to electronic documents that ensure their security, such as the electronic seal, time stamp or the service of registered electronic delivery. In some cases, the electronic seal will be used in the aspect of e-prescriptions - depending on the model of the system. Until the introduction of the eIDAS regulation, neither the European electronic system nor the national electronic seal had been defined or regulated. As stated in the binding EU regulation: "the electronic seal refers to data in electronic form added to other data in electronic form or logically related to them, to ensure the authenticity of their origin and integrity of related data (Art. 3.25)" [14].

It is worth clarifying here that the electronic signature and seal resemble their paper counterparts only in name. The idea of the digital signature and seal is based on the creation of the mechanism of the so-called trusted third party. The idea is that, apart from the entities using digital signatures, there is an entity that issues certificates confirming the identity of certain individuals and institutions. These institutions are trust service providers who had to undergo the accreditation process by the 'conformity assessment body' checking compliance with the requirements of the eIDAS regulation. The 'conformity assessment body' issues relevant reports confirming the role exercised by the suppliers of the reports, which can be requested by the supervisory body at any time during the audit [14].

Particularly important mechanisms enabling the use of e-prescriptions are the uniform tools that - on the one hand - ensure the security of e-documents, their interoperability and - on the other - the acceptance of electronic signatures and seals throughout the EU. The basic principle adopted was that every country providing access to services via ICT networks must provide this access to all EU citizens, and if these countries have introduced the possibility of their citizens receiving identification means, they must also be recognized throughout the entire European Union.

Additionally, it is worth mentioning that the eIDAS regulation contains attachments (called requirements), which describe in detail i.a. what standards must be met by the electronic seal and signature (along with the certificates assigned to them) to ensure safety of their use. These requirements are guidelines for creating trust services and systems that support these tools [14].

Returning to the tools recommended by the eIDAS regulation, the electronic time stamp "are data in electronic form that bind other data in an electronic form with a certain time, being evidence that these other data existed at a given time" (Article 3.33), while electronic registered delivery service "refers to a service that allows data to be sent between third parties electronically, and that provides evidence related to the use of transmitted data, including proof of sending and receiving data, and protecting transmitted data against the risk of loss, theft, damage or any unauthorized change" (Article 3.36) [14].

The provisions included in the eIDAS regulation do not create restrictions on the technologies used in trust services, which gives the opportunity to apply innovative technologies such as cloud computing. The companies that have used this technological solution are, for example, SkIDentity and FutureID. They offer - in the form of services - the architecture of electronic delivery and electronic signature tools, seals and certificates. This means that all data relating to these elements is stored outside the place of service provision (e.g. a pharmacy), in a secure manner. Experts estimate that over the years such solutions will become more and more popular - inevitably, also in the health care sector [29].

The eIDAS regulations do not apply to the provision of trust services used only within closed systems operating under national law or agreements concluded by a specific group of participants (Article 2) [14].

In the law on e-prescription [8], the Polish legislator allows use of the ZUS tool to sign e-leaves, which currently operates in the internal information flow system serving the authentication of electronic medical records, in this case e-prescriptions contained in an open, external system, thus creating a third form of confirming identity, along with the trusted ePUAP profile and qualified signature [30].

There is some inconsistency with the law, namely the fact that the internal tool confirming $Z U S$ identity does not meet the requirements of the eIDAS regulation, and so should not be used as a universal tool for signing electronic documents (e-prescriptions) outside the parent institution, i.e. in an open system with other entities.

\section{New tools and changes within the structure of the national identification system}

As of today, the Polish legislator allows three methods mentioned above to sign electronic documents [1]. However, the draft law introduces new tools that will allow providing better standards in the scope of security of the content contained in e-prescriptions, and the greater universality of free-of-charge solutions, available both to entities authorized to issue and to receive prescriptions.

\subsection{ID card with an electronic layer}

In a few months, a multifunctional identity card is expected to enter into force (planned starting from March 2019). It is to constitute a free-of-charge, state-owned electronic identification method. This document will be a clear and undeniable confirmation of the identity of the citizen. It will also be used for the authentication in e-services used in public administration and for signing electronic documents, as well as for confirming presence in ICT systems. The new ID will have an ICAO application (travel document with the biometric feature 
called 'face image') and electronic data, which together with data known only to the holder of this ID, will allow to authenticate it in ICT systems used to provide online services, as well as for signing electronic documents with an electronic signature [31]. Once the new ID has come into force, a personal signature will appear, i.e. an advanced electronic signature within the meaning of the eIDAS regulation, and importantly, it will be able to be submitted without the need to access the Internet (using a reader). The advanced electronic signature has the following features: uniquely assigned to the signer, allows determining the identity of the signer, submitted using data known only to the signer, and making it possible to notice any subsequent change in the signed document. Using a personal electronic signature in a public entity will have the same effect as a handwritten signature, and in the case of another entity the same effect will arise, provided the subject and the holder of the ID card consent to it. Notwithstandingly, the new ID will allow the placement of a qualified electronic signature certificate issued by commercial suppliers [31]. Three functionalities of the new ID necessary for the functioning of the e-prescription are:

- authentication of the identity card holder in teleinformation systems (identification and authentication certificate);

- confirmation of the presence of the holder of the ID card at a specified time and place or participation in services (certificate of presence confirmation);

- placement of a personal signature (personal signature certificate) [31].

According to the new concept, a citizen choosing an ID card containing an electronic layer will gain a means of electronic identification (an intangible unit containing data identifying the person, needed for the authentication process for online services) called the 'personal profile', and the option of creating an electronic signature ("personal signature') fulfilling European Union standards. In addition, the name of another existing electronic identification means, 'trusted ePUAP profile' will be changed to 'trusted profile', and the currently implemented tasks, will be excluded - in legal and technical terms - from the responsibilities of the ePUAP [Electronic Platform of Public Administration Services]. Also the functionality of covering electronic documents with 'a signature confirmed by a trusted profile' will be eliminated. A separate 'public electronic identification system' will be created (teleinformation system), whose task will be to support two means of electronic identification, 'personal profile'; 'trusted profile' and 'trusted signature' tool, which will replace 'signature confirmed with a trusted profile'. The authenticity of a trusted signature placed on an electronic document will be guaranteed by an electronic seal of the minister in charge of computerization. 'Trusted profile' will be a means of electronic identification ensuring a medium level of trust (security), and so applicable to most online services, but not in medical records and not outside of Poland. Its use will require providing the login, password and entering the code received on the user's mobile phone. Submission of the 'trusted signature' will be possible using the 'trusted profile' as well as the 'personal profile'. Under the new rules, the public entity will be able to authenticate the individual using the 'trusted profile' and 'personal profile', while non-public entities will be able to authenticate only using the 'personal profile'. The 'public electronic identification system' will be integrated with the 'national node', in this way imposing on each entity wishing to integrate its own service platform with this ICT system, the requirement of recognition of the authentication of a physical person using a foreign electronic identification means [31].

\subsection{Electronic identification system}

In order to send e-prescriptions, an electronic system supporting electronical prescriptions needs to be connected to the Electronic Identification Node. In short, this node refers to the structure as such together with the entire digital architecture, which in one place integrates electronic identification systems (e.g. Trusted Profile), ICT systems of public services (e.g. ePUAP, ZUS PUE, RUM NFZ) and - optionally - public attributes (e.g. PESEL) - defined as individual identifiers serving to verify the identity of a natural or legal person, determined in accordance with national law, and which can be used in qualified certificates if they do not interfere with crossborder interoperability [14]. In addition, the use of both identifiers and commercial attributes (offered by banks and other entities for use in the public electronic identification system) is allowed [32].

\subsection{Medical specialist card}

From the beginning, the implementation of the information system in health care entailed the issuing of special tools, i.e. KSM (Medical Specialist Card), KSA (Administrative Specialist Card) - for service providers and for e-KUZ (Electronic Health Insurance Card) - for patients, which would enable both issuing e-prescriptions as well as their reception. It should be noted here that e-KUZ is a different tool to the existing European Health Insurance Card (EHIC), which indicates that you have health insurance. Simultaneously with the work on e-KUZ, the concept of a new ID with an electronic layer was implemented. Unfortunately, both of these tools have remained only conceptual.

Legislative work is underway to create new documents with an electronic layer, i.e. "Rights to practise as a physician" and "Rights to practise as a dentist". They are supposed to function in the form of polycarbonate cards with the dimension and security measures similar to the ID card. In the future, the right to practise as a doctor or dentist will simultaneously constitute the Medical Specialist Card (Pol. KSM), and should therefore enable the identification and authentication of a medical professional for the purpose of providing healthcare services. It is connected with the necessity of equipping the document with a microprocessor (or other data medium), which will make it possible for it to be assigned the functionality of the electronic signature [33, 34]. 
The launching of the e-prescription project must be preceded by activities that will result in equipping all the persons entitled with the tools necessary for signing (electronic signatures) and guaranteeing the integrity of the signed content and making it possible to verify its authenticity (electronic seals). The implementation of these tools is a necessity in order to make sure that the e-prescription concept is compliant with the solutions.

\section{Electronic prescription in other countries}

The electronic prescription has long been used in many developed countries. Sweden is the country where the process of implementing electronic prescriptions started very early. Work on the implementation of this solution had begun as early as in 1983, while the launch of the advanced system took place in 2004 [35].

\subsection{The way the e-prescription system works in Sweden}

In Sweden, Sjunet is a dedicated system for the processing of e-prescription data. Most pharmacies and entities providing health services have access to this network (which does not require connection to the Internet), but the network can be accessed also by other units [36].

The prescription is issued in an electronic form by a physician, by means of an electronic system, from where it is immediately sent to the central database or to the pharmacy indicated by the patient. If the document is sent to the database, the e-prescription can be bought at any pharmacy (within the country). In order to execute the e-prescription, the patient's identity must be confirmed by the pharmacist. The advantage of sending e-prescriptions to a pharmacy indicated by the patient is that the pharmacist can prepare the prescribed product earlier. The fact that the network is not connected to the Internet contributes to securing the processed data, thanks to which only the issuing persons and pharmacy employees have access to them. In addition, the creation of a central database allows access to information on e-prescriptions previously issued to a given patient, which in turn, avoids the repeated prescribing of the same preparations [36, 37].

A simplified diagram of the functioning of the Swedish e-prescription system is shown in Figure 2.

The successful implementation of Sjunet was mainly due to the advanced level of digitization of entities providing health services and to the close cooperation of the above-mentioned facilities (especially at the local level) with the state network of pharmacies (Apoteket $\mathrm{AB}$ ) holding exclusive rights to trade in medicines until 2010, which enabled the creation of a national database containing data on the execution of e-prescriptions. In addition, the factors that contribute to the Swedish e-prescription system being recognized as one of the most effective solutions are: the creation of the Sjunet network and training for medical personnel (mainly doctors) on proper document completion, as well as training for patients aimed at increasing public awareness of the benefits of implementing the planned solution [38], [36]. Thanks to the multi-stage implementation of the system of e-prescriptions, they constitute about $90 \%$ of all pre-

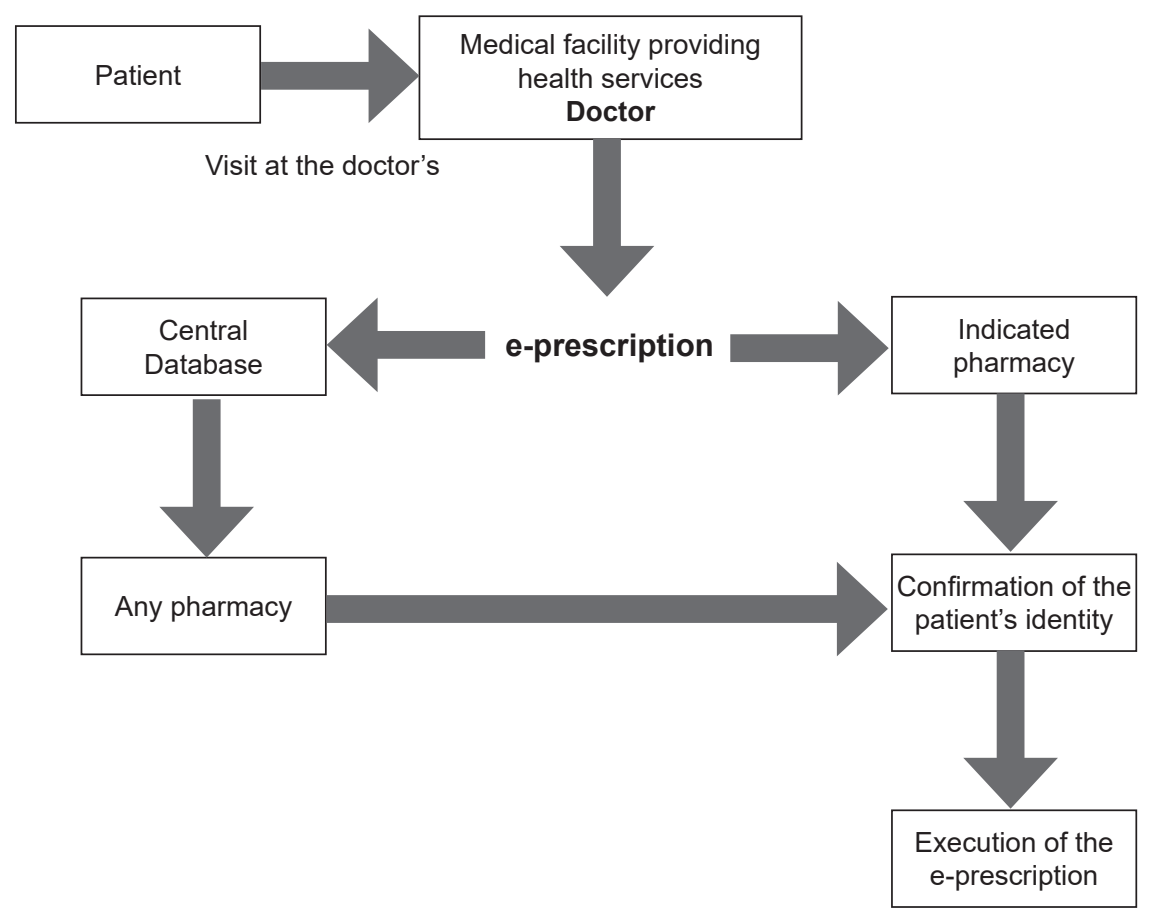

Figure 2. Diagram of the functioning of the Swedish e-prescription system.

Source: Own elaboration. 
scriptions issued by doctors in Sweden [39]. In addition, the study conducted in 2011 shows that the vast majority of patients in Sweden report positive experiences related to the use of e-prescriptions [37].

\subsection{Electronic prescription in Spain}

The e-prescription system operates also in Spain. In contrast to Sweden, the system created in Spain is decentralized, which means that each region of the country has a separate solution for processing data on the aforementioned documents [35].

One of the best-functioning e-prescription systems in Spain is the 'Receta XXI' operating in Andalusia. This system can be accessed by primary care facilities, emergency medical services and centres providing outpatient services - both within state and private health insurance), and includes electronic medical records containing medical data of patients acquired from the Diray system. Combining both systems allows continuous access to the history of patients' diseases, which in turn facilitates writing out e-prescriptions [40].

The patient who comes to the doctor is obliged to present a card (with an electronic layer) confirming the possession of health insurance. The card enables access to the patient's electronic record and confirmation of their identity, which is necessary for writing out the e-prescription. The person writing out the document can also use a digital dictionary of medicinal products with information on doses, mode of action and the use of individual substances, which is updated on a monthly basis [40].

The e-prescription issued by the doctor is stored in the Receta XXI system, while the Diraya system records data on the preparations given out to each patient. The e-prescription can be executed by the patient in any pharmacy, subject to its affiliation to the system. In order to execute the prescription, it is also necessary for the patient to show the card enabling confirmation of their health insurance, which at the same time guarantees the pharmacist's access to the system processing the data on e-prescriptions. In turn, the pharmacist is obliged to have a card identifying the pharmacy (confirming its affiliation to the system) [40].

There are three ways to write out prescriptions in the Spanish region of Andalusia. The first one is to complete the document in handwriting, and then introduce its content to the system. This method is particularly useful for home visits. The second method is to write out the prescription in electronic form and print out its paper version, which is then passed on to the patient, and so its execution in the pharmacy takes place in a traditional way. The third method is to fill in the document in the Receta XXI system and send it to the central system, thanks to which it can be executed at any pharmacy (the pharmacist can access it through the system). In this case, it is also possible to print out a prescription for the patient in order for them to obtain information on dosage, for example; however, they do not need to present a printout in order to buy medicines in the pharmacy [40].

The diagram presenting the e-prescription system in Andalusia is shown in Figure 3.

The advantages of the implemented system include, above all: enabling patients to access the prescriptions issued for them (e.g. during a doctor's check-up visit or at a pharmacy), increasing security and saving medical staff time. The success of the e-prescription system in Andalusia is also due to the gradual expansion of the area of operation of this network and the possibility of responding to emerging problems, as well as the creation of cooperation opportunities for systems used in various regions of the country [40].

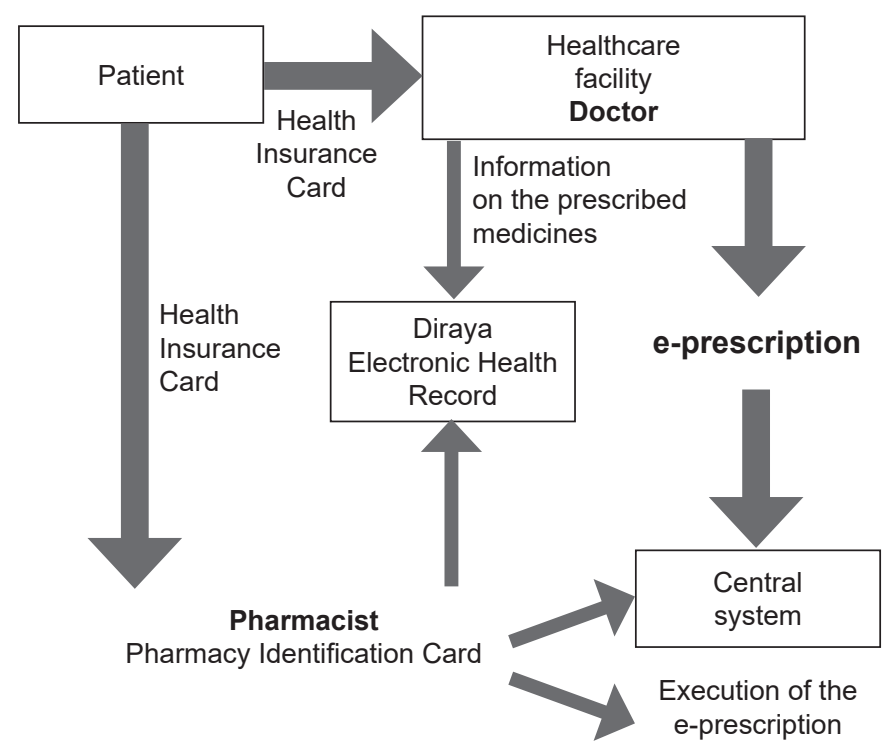

Figure 3. Diagram of the functioning of the e-prescription system in Andalusia.

Source: Own elaboration. 


\section{Conclusions}

Taking into account the advancement of information technology, the introduction of the e-prescription system is simply inevitable. The implementation of the system will be beneficial to all entities in the medical services market, i.e. patients, the state participating in the reimbursement of the medicines, and the entities that write out the medicines. The introduction of the e-prescription model is unfeasible without a system serving the identification of both the person entitled to issue e-prescriptions as well as patients entitled to use state funding. In addition, it is necessary to identify the medical entities in which services related to the issuing of the prescription were performed. Lastly, the entities issuing the prescriptions must use tools that will ensure:

- confidentiality - data protection against disclosure to unauthorized persons;

- integrity - securing data and electronic documents before the change;

- credibility - ensuring the possibility of identifying the entity issuing the e-prescription in the electronic world. The e-prescription system must be fully compatible with the systems used by all entities maintaining medical documentation. Separate handling of electronic medical records - one where the authorized entity will register medicines written out for the patient and another used to support the electronic prescription - is unacceptable.

\section{References}

1. Ustawa z dnia 6 września 2001 r. Prawo farmaceutyczne. (Dz.U. $2001 \mathrm{Nr} 126$ poz. 1381).

2. Rozporządzenie Ministra Zdrowia z dnia 13 kwietnia $2018 \mathrm{r}$. w sprawie recept (Dz.U. 2018 poz. 745).

3. Ustawa $z$ dnia 28 kwietnia 2011 r. o systemie informacji w ochronie zdrowia (Dz.U. $2011 \mathrm{Nr} 113$ poz. 657).

4. Pachocki J. et al., Raport: Jak skutecznie wykorzystać potencjat telemedycyny w polskim systemie zdrowia? Fundacja Telemedyczna Grupa Robocza, Warszawa 2018.

5. Sośnierz A., E-recepta. Nareszcie! "Służba Zdrowia” 2018; 17-25: 19.

6. Komisja Europejska, Badanie pulsu e-zdrowia w Europierecepta $w$ postaci szerszego wykorzystywania technologii informacyjnych i telekomunikacyjnych przez lekarzy. 6 września 2018; http://europa.eu/rapid/press-release_IP08-641_pl.htm (accessed: 6.09.2018).

7. Boczek K., Zamki na e-piasku, "Służba Zdrowia" 2018; 34-42: 52-56.

8. Ustawa z dnia 1 marca 2018 r. o zmianie niektórych ustaw w związku z wprowadzeniem e-recepty (Dz.U. z 2018 poz. 697).

9. Centrum Systemów Informacyjnych Ochrony Zdrowia; https://www.csioz.gov.pl/\# (accessed: 28.09.2018).

10. NFZ w Łodzi. Plakat Instruktażowy Narodowego Funduszy Zdrowia w Łodzi; https://www.nfz-lodz.pl/attachments/article/8006/05_plakat_instrukcja-A2.pdf (accessed: 14.09.2018).

11. Dyrektywa Parlamentu Europejskiego i Rady 2011/24/ UE z dnia 9 marca 2011 r. w sprawie stosowania praw pacjentów w transgranicznej opiece zdrowotnej.
12. Dyrektywa Wykonawcza Komisji 2012/52/UE z dnia 20 grudnia 2012 r. ustanawiająca środki ułatwiające uznawanie recept lekarskich wystawionych w innym państwie członkowskim.

13. Ustawa z dnia 17 lutego 2005 r. o informatyzacji działalności podmiotów realizujących zadania publiczne (Dz.U. $2005 \mathrm{Nr} 64$ poz. 565).

14. Rozporządzenie Parlamentu Europejskiego i Rady (UE) 910/2014 z dnia 23 lipca 2014 r. w sprawie identyfikacji elektronicznej i usług zaufania w odniesieniu do transakcji elektronicznych na rynku wewnętrznym oraz uchylające dyrektywę 1999/93/WE.

15. Rozporządzenie Ministra Zdrowia z dnia 9 listopada 2015 r. w sprawie rodzajów, zakresu i wzorów dokumentacji medycznej oraz sposobu jej przetwarzania Na podstawie art. 30 ust. 1 ustawy z dnia 6 listopada 2008 r. o prawach pacjenta i Rzeczniku Praw Pacjenta (Dz.U. z 2012 r. poz. 159, z późn. zm. 2).

16. Pusz M., Centrum Systemów Informacyjnych Ochrony Zdrowia. Instrukcja stosowania Polskiej Implementacji Krajowej HL7 CDA WERSJA 1.2, Warszawa 2017; https://www.csioz. gov.pl/HL7POL/pl-cda-html-pl-PL/ (accessed:28.09.2018).

17. Ustawa z dnia 5 września 2016 r. o usługach zaufania oraz identyfikacji elektronicznej (Dz.U. 2016 poz. 1579).

18. Rozporządzenie Parlamentu Europejskiego i Rady (UE) 2016/679 z dnia 27 kwietnia 2016 r. w sprawie ochrony osób fizycznych w związku z przetwarzaniem danych osobowych i w sprawie swobodnego przepływu takich danych oraz uchylenia dyrektywy 95/46/WE (ogólne rozporządzenie o ochronie danych).

19. Ustawa z dnia 5 lipca 2018 r. o krajowym systemie cyberbezpieczeństwa (Dz.U. 2018 poz. 1560).

20. Dyrektywa Parlamentu Europejskiego i Rady (UE) 2016/1148 z dnia 6 lipca 2016 r. w sprawie środków na rzecz wysokiego wspólnego poziomu bezpieczeństwa sieci i systemów informatycznych na terytorium Unii.

21. Marucha-Jaworska M., Rozporządzenie eIDAS: zagadnienia prawne i techniczne. Wyd. 1. Wolters Kluwer Polska, Warszawa 2017.

22. Centrum Systemów Informacyjnych Ochrony Zdrowia, Rekomendacje Centrum Systemów Informacyjnych Ochrony Zdrowia $w$ zakresie bezpieczeństwa oraz rozwiazań technologicznych stosowanych podczas przetwarzania dokumentacji medycznej w postaci elektronicznej, Warszawa 2017; https://www.csioz.gov.pl/aktualnosci/szczegoly/ rekomendacje-w-zakresie-bezpieczenstwa-oraz-rozwiazantechnologicznych-stosowanych-podczas-przetw/ (accessed: 22.11.2018).

23. eHealth DSI Operations. ePrescription and Patient Summary use cases; https://ec.europa.eu/cefdigital/wiki/display/ EHOPERATIONS/ePrescription+and+Patient+Summary+ use+cases\#ePrescriptionandPatientSummaryusecases-ePrescription (accessed: 28.09.2018).

24. eHealth Network. Guideline on an Organisational Framework for eHealth National Contact Point, 2015; http:// ec.europa.eu/health/ehealth/docs/ev_20151123_co01_en.pdf (accessed: 28.09.2018).

25. Komisja Europejska, Connecting Europe Facility in Telecom; http://ec.europa.eu/digital-agenda/en/connectingeurope-facility (accessed: 28.09.2018). 
26. Centrum Systemów Informacyjnych Ochrony Zdrowia, Elektroniczna Dokumentacja Medyczna; https://csioz.gov. pl/edm/ (accessed: 22.11.2018).

27. Pejaś J. et al., Wdrożenie rozporządzenia eIDAS w Polsce. Raport Wersja 4.2, 2014.

28. Dumortier J., Regulation (EU) No 910/2014 on Electronic Identification and Trust Services for Electronic Transactions in the Internal Market (eIDAS Regulation), 1 lipca 2016; https://papers.ssrn.com/abstract=2855484 (accessed: 23.11.2018).

29. Hühnlein D., Towards eIDAS as a Service, in: Reimer H., Pohlmann N., Schneider W. (reds), ISSE 2014 Securing Electronic Business Processes, Springer Fachmedien, Wiesbaden 2014: 241-218; https://www.ecsec.de/fileadmin/Ecsec-files/pub/ISSE_2014-final.pdf (accessed: 15.09.2018).

30. Ustawa z dnia 5 lipca 2018 r. o zmianie ustawy o usługach zaufania oraz identyfikacji elektronicznej oraz niektórych innych ustaw (Dz.U. 2018 poz. 1544).

31. Uzasadnienie do „Rządowego projektu ustawy o zmianie ustawy o dowodach osobistych oraz niektórych innych ustaw"; https://bip.mswia.gov.pl/bip/projekty-aktow -prawnyc/2018/25570,Projekt-ustawy-o-zmianie-ustawy o-dowodach-osobistych-oraz-niektorych-innych-ust.html (accessed: 24.09.2018).

32. Accenture, Obserwatorium.biz. Raport eID 2017. Elektroniczna identyfikacja w Polsce, 2017; https://www.accenture. com/pl-pl/event-eid-report-2017 (accessed: 24.09.2018).

33. Ustawa z dnia 21 października 2016 r. o zmianie ustawy o zawodach lekarza i lekarza dentysty oraz niektórych innych ustaw (Dz.U. 2016 poz. 2020).

34. Ustawa z dnia 20 lipca 2018 r. o zmianie ustawy o systemie informacji w ochronie zdrowia oraz niektórych innych ustaw (Dz.U. 2018 poz. 1515).
35. Kierkegaard P., E-Prescription across Europe, "Health Technol.” 2013; 3 (3): 205-19; https://link.springer.com/article/10.1007/s12553-012-0037-0 (accessed: 23.11.2018).

36. Landberg C., Apoteket and Stockholm County Council, Sweden: eRecept, an ePrescribing application, Bonn 2006.

37. Hammar T., Nyström S., Petersson G., Åstrand B., Rydberg T., Patients satisfied with e-prescribing in Sweden: a survey of a nationwide implementation, "Journal of Pharmaceutical Health Services Research" 2011; 2 (2): 97-105; https:// onlinelibrary.wiley.com/doi/abs/10.1111/j.1759-8893.2011. 00040.x (accessed: 24.11.2018).

38. Stroetmann K.A. et al., eHealth is Worth it The economic benefits of implemented eHealth solutions at ten European sites, European Communities 2006; https://www.researchgate.net/publication/264167211_eHealth_is_Worth_it_The economic_benefits_of_implemented_eHealth_solutions_at ten_European_sites?fbclid=IwAR3wQf4LxvWH_Dq9GmAWQDcg2rGQP6y-UucVAsMRcLoSZAy3XFHqYTq8ojw (accessed: 23.11.2018).

39. Deetjen U., European E-Prescriptions: Benefits and Success Factors, Oxford Internet Institute University of Oxford, Oxford 2016; https://www.politics.ox.ac.uk/materials/ publications/15224/workingpaperno5ulrikedeetjen.pdf (accessed: 23.09.2018).

40. Vatter Y. et al., Receta XXI, The regional ePrescribing system of Andalucia's public health service, Spain, Bonn 2009; https://ec.europa.eu/eip/ageing/sites/eipaha/files/results_attachments/ehri case receta xxi_final-2009.pdf (accessed: 23.09.2018). 